\title{
Comparison of Histamine Release Induced by Synthetic Polycations with That by Compound 48/80 from Rat Mast Cells
}

\author{
Yasushi YOSHINO, Kohi NAGAYA, Hidehito SEKINO, \\ Masaatsu K. UCHIDA and Tamiko SUZUKI-NISHIMURA* \\ Department of Molecular Pharmacology, Meiji College of Pharmacy, \\ 1-35-23 Nozawa, Setagaya-ku. Tokyo 154, Japan
}

Accepted November 8,1989

\begin{abstract}
We compared the histamine release induced by polyethylenimines and polyallylamires with that induced by compound $48 / 80$. Lidocaine inhibited the histamine release induced by polyethylenimine with a molecular weight of 600 $\left(\mathrm{PEI}_{6}\right)$, but disodium cromoglycate did not. The histamine releases induced by all polyethylenimines and polyallylamines tested were inhibited by lidocaine, but not by disodium cromoglycate. islet activating protein inhibited the histamine release induced by $\mathrm{PEI}_{6}$. Its effects on the release by other polyethylenimines and polyallylamines were less than that on $\mathrm{PEI}_{6}$. It is likely that the inhibition of $\mathrm{G}$ proteins by islet activating protein resulted in a decrease of the histamine release. This possibility was supported by the finding that guanyl- $5^{\circ}-(\beta . \gamma$-imino $)$ triphosphate enhanced the histamine release. An inhibitor of polyphosphoinositide phosphodiesterase, neomycin. did not affect the histamine releases induced by these polymers. The effect of $\mathrm{PEI}_{6}$ seemed to resemble that of compound 48/80. After pretreatment of mast cells with wheat germ agglutinin and with Limax flavus agglutinin, releases of histamine induced by $\mathrm{PEI}_{6}$ and compound $48 / 80$ decreased. suggesting that the binding sites of $\mathrm{PEI}_{6}$ and compound $48 / 80$ had sialic acid and/ or $\mathrm{N}$-acetyl glucosamine residues. The binding site for $\mathrm{PEI}_{6}$ seemed to especially overlap those of compound $48 / 80$.
\end{abstract}

Our group previously reported that synthetic polycations with various molecular weights [polyethylenimines (PEIs) and polyallylamines (PAAs), ref. 1] released histamine from rat mast cells (2). PEls and PAAs are simpler than compound $48 / 80$ in chemical structure and are stable in aqueous solution. Unlike their fusogenic activites (1), histaminereleasing potencies of these polymers were nor affected simply by the polymerization, as

\footnotetext{
* To whom correspondence snould be addressed. Abbreviaticns: $\mathrm{PEI}_{\underline{\mathbf{x}}}$. polyethylenimine with a molecular weight of $(x \times 100)$; PAA $A_{x}$. polyallylamine with a molecular weight of $(\underline{x} \times 100)$ : DSCG. disodium cromoglycate; IAP. islet activating protein; GppNHp. guanyl- $5^{-}-(\beta, \gamma$-imino) triphosphate: Con $A$, concanavalin $A$ : PHA, phytohemagglutinin: WGA, wheat germ agglutinin: LFA. Limax flavus agglutinin.
}

Was compound $48 / 80(3)$; the histamine releases induced by $\mathrm{PEI}_{6}, \mathrm{PEI}_{12}$ and $\mathrm{PEI}_{100}$ were more than those by triethylentetramine and $\left.P E\right|_{18}$, while that by $P A . A_{30-40}$ was similar to that of $\mathrm{PAA}_{100}(2)$.

There are three types of histamine release inhibitors from rat mast cells: specific inhibitors of histamine release mediated by $\lg E$ receptors, such as methoxy verapamil (D-600, a calcium antagonist) and disodium cromoglycate $(D S C G)(4,5)$; specific inhibitors of release induced by compound $48 / 80$. such as islet activating protein (IAP) $(6.7)$; and inhibitors of both histamine releases mediated by $\lg E$ receptors and compound $48 / 80$, such as dibutyryl cyclic AMP and local anesthetics $(8-10)$. The histamine releases induced by PEIs and PAAs were inhibited by dibutyry cyclic $\triangle M P$, but not by D-600, and D-600 
did not block the increase in intracellular calcium concentrations by polycations (2).

In this study, we compared the effects of lidocaine, DSCG and IAP on histamine releases induced by PEIs and PAAs with those induced by compound 48/80. Mechanisms of action of IAP were further examined using a GTP analogue and neemycin; the GTP analogue released histamine from permeabilized mast cells by ATP or streptolysin-O: and neomycin (an inhibitor of polyphosphoinositide phosphodiesterase) inhibited the release only from the permeabilized cells by ATP $(11,12)$. We also examined the effects of lectins, which recognize specific sugar residues, on hiistamine releases induced by polycations and discussed possible receptor sites of polycations and compound $48 / 80$ on mast cells.

\section{Materials and Methods}

Preparation of purified mast cells: Mast cells from the peritoneal cavity of male Sprague-Dawley rats, weighing 300-350 g. were purified using Ficoll 400 (Pharmacia) as previously described (4). The purity of the mast cells in the final preparation was more than $90 \%$

Assay of histamine release from rat mast cells: A $1-\mathrm{ml}$ sample of cell suspension ( $5 \times$ $10^{4}$ cells) in Hepes-buffered Tyrode solution was preincubated at $37^{\circ} \mathrm{C}$ for $10 \mathrm{~min}$ and then incubated with polvcations for another 10 min. The cells were treated with lidocaine and lectins for $10 \mathrm{~min}$ and DSCG for $10 \mathrm{sec}$ before adding the polycation. The mast cells were exposed to IAP by incubating the cell suspension $\left(10^{6}\right.$ cells $\left./ \mathrm{ml}\right)$ in Hepes-buffered Tyrode solution containing various amounts of IAP under $95 \% \mathrm{O}_{2} / 5 \% \mathrm{CO}_{2}$ at $37^{\circ} \mathrm{C}$ for $2 \mathrm{hr}$ The cells were then washed twice or three times $\left(150 \times \mathrm{g}, 4^{\circ} \mathrm{C}, 5 \mathrm{~min}\right)$ and resuspended in Hepes-buffered Tyrode solution. Mast cells were permeabilized with 150 " M ATP in the absence of divalent cations (11), and the GTP analogue and neomycin were loaded into the permeabilized mast cells at $37^{\circ} \mathrm{C}$ for $5 \mathrm{~min}$ in Hepes-buffered Tyrode solution. because these molecules were membrane impermeable. To reseal the cells, they were then incubated with $1 \mathrm{mM} \mathrm{MgCl}$ at $37^{\circ} \mathrm{C}$ for $5 \mathrm{~min}$ and then washed in $\mathrm{Ca}$-free Hepes- buffered Tyrode solution. The washed cells were resuspended in $\mathrm{Ca}$-free Hepes-buffered Tyrode solution and preincubated for $5 \mathrm{~min}$. They were then incubated successively with $1 \mathrm{mM} \mathrm{CaCl}_{2}$ for $5 \mathrm{~min}$.

After treatment with various drugs, the cells were then incubated with polycations $(10 \mu \mathrm{g} / \mathrm{ml})$ or compound $48 / 80(1 \mu \mathrm{g} / \mathrm{m} !)$ for $10 \mathrm{~min}$. Ice-cold Hepes-buffered Tyrode solution $(1.8 \mathrm{ml})$ was added to terminate the reaction, and the mixture was centrifuged at $2,100 \times \mathrm{g}$ for $10 \mathrm{~min}$ at $4^{\circ} \mathrm{C}$. Histamine in the supernatant was determined using the fluorometric assay of Shore et al. (13). Histamine release was calculated as a percentage of the total cell content. Values for histamine release are given as means $\pm S . E$. for three or four replicate experiments on different samples of pooled cells. As previously described (2), PEIs and PAAs release histamine from intact mast cells dose-dependently. The histamine releases induced by $\left.P E\right|_{0}, P E I_{12}, P E I_{18}, P E I_{100}, P A_{30-40}$ and $P A A_{100}(10 \mu \mathrm{g} / \mathrm{ml})$ in $10 \mathrm{~min}$ at $37^{\circ} \mathrm{C}$ were $63.1 \pm 2.3(n=19), 66.2 \pm 1.2 \quad(n=18), 42.6 \pm$ $2.4(n=17), 59.1 \pm 3.5(n=21), 64.8 \pm 1.7(n=$ $21)$ and $62.2 \pm 2.4(n=21) \%$ of the total content, respectively. The spontaneous histamine release was $6.35 \pm 0.46 \% \quad(n=32)$. Histamine-releasing potencies of polycations $(10 \mu \mathrm{g} / \mathrm{ml})$ were reduced after incubation of the cells in the absence of IAP for $2 \mathrm{hr}$; the histamine release as a \% of the total cell content of these cells stimulated by $\mathrm{PEI}_{6}, \mathrm{PEI}_{12}$. $\mathrm{PEI}_{18}, \mathrm{PEI}_{100}, \mathrm{PAA}_{30-40}$ and $\mathrm{PAA}_{100}$ were $37.8 \pm 2.1 \quad(n=6), 40.9 \pm 4.7 \quad(n=7), 11.0 \pm 2.0$ $(n=6), 53.1 \pm 2.6(n=7), 53.5 \pm 1.7(n=7)$ and $51.6+4.0(n=6) \%$, respectively. Spontaneous histamine release was not affected by pretreatment of the cells with DSCG, IAP or neomycin. The inhibitory effects of the drugs were calculated by the following equation:

$\%$ Inhibition $=100-[$ (histamine release with drug) - (spontaneous release) $] /$ [(histamine release without drug) -(spontaneous release) $] \times 100$

Statistical analyses: Statistical significance was evaluated by the unpaired Student's $t$ test, and $P=0.05$ was taken as the upper limit of significance.

Chemicals: Polycations (Fig. 1) were gifts from Drs. N. Oku and M. Nango. The islet ac- 
A<smiles>CN(C)CCN(CCN)CCN</smiles>

B

$$
+\mathrm{CH}_{2}-\left.\right|_{\mathrm{NH}_{2}} ^{\mathrm{CH}} \mathrm{H}_{2}
$$

Fig. 1. Structures of polyethylenimine (A) and polyallylamine (B).

tivating protein was from Funakoshi Pharmaceutical Co. (Tokyo, Japan). Guanyl-5: ( $\beta, \gamma$-imino) triphosphate (GppNHp, tetralithium salt) and ATP were purchased from Boehringer-Mannheim Yamanouchi (Tokyo, Japan) and Wako Pure Chemicals (Osaka, Japan), respectively, Lidocaine $\mathrm{HCl}$ and DSCG (Intal $\left.{ }^{\mathbb{R}}\right)$ were gifts from Fujisawa Pharmaceutical Co. (Osaka, Japan). Compound 48/80, neomycin sulfate and concanavalin A (Con A) were purchased from Sigma Chemical Co. (St. Louis. MO). Phytohemagglutinin (PHA) and Limax flavus agglutinin (LFA) were purchased from $E Y$ Laboratories (San Mateo, CA) and wheat germ agglutinin (WGA) was from Honen Corp. (Tokyo, Japan). Hepes [4-(2-hydroxyethyl)-1-piperazineethanesulfonic acid] was purchased from Dojindo Laboratories (Kumamoto, Japan). Hepes-buffered Tyrode solution had the following composition: 137 $\mathrm{mM} \mathrm{NaCl}, 2.7 \mathrm{mM} \mathrm{KCl}, 12 \mathrm{mM}$ Hepes. $1 \mathrm{mM}$ $\mathrm{MgCl}_{2}, 1 \mathrm{mM} \mathrm{CaCl}$. $5.6 \mathrm{mM}$ dextrose and $0.03 \%$ bovine serum albumin, pH 7.4. Cafree Hepes-buffered Tyrode solution had the same composition, but without $\mathrm{CaCl}_{2}$.

\section{Results}

Effects of lidocaine and DSCG on histamine release induced by polycations: The inhibitory effects of lidocaine on histamine releases induced by PEls and PAAs are shown in Fig. 2 as \% inhibition: its IC50 values for $\left.P E\right|_{6}$. $\mathrm{PEI}_{12}, \mathrm{PE} !_{18}, \mathrm{PEI}_{100}, \mathrm{PAA}_{30-40}$ and $\mathrm{PAA}_{100}$

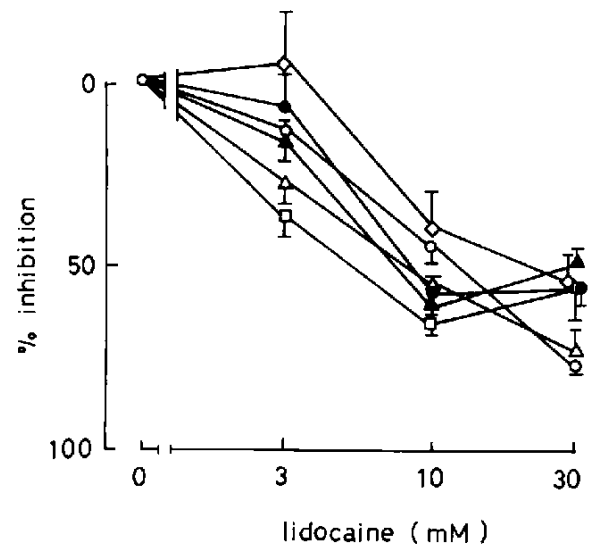

Fig. 2. Inhibitory effects of lidocaine on histamine release induced by $\mathrm{PEI}$ and PAAs. Purified mast cells were preincubated with lidocaine for $10 \mathrm{~min}$, and polycation $(10 \mu \mathrm{g} / \mathrm{ml})$ was added. After $10 \mathrm{~min}$, the reaction was stopped and the cell suspension was centrifuged. The histamine content of the supernatant was determined, and the $\%$ inhibition was calculated. Values are means \pm S.E. for 6 to 8 replicated experiments. When no vertical bar is shown, the S.E. was less than $2 \% . \bigcirc, \mathrm{PEI}_{6}: \triangle, \mathrm{PFI}_{12} ; \mathrm{L}$. . PEI ${ }_{18} ; \diamond . \mathrm{PEI}_{100}$; - $\mathrm{PAA}_{30-40} ; \mathbf{A}$. PAA 100 .

were $12.5,8.0,5.2,19.4,8.4$ and $7.3 \mathrm{mM}$. respectively. Its inhibitory effects on histamine releases induced by $\mathrm{PEI}_{6} . \mathrm{PEI}_{12}$ and $\mathrm{PEI}_{100}$ increased with an increase in its concentration, although the values for histamine release by $\mathrm{PEI}_{18}, \mathrm{PAA}_{30-40}$ and $\mathrm{PAA}_{100}$ reached a plateau at a concentration of $10 \mathrm{mM}$. Lidocaine $(10 \mathrm{mM})$ also inhibitect the histamine release when added only $10 \mathrm{sec}$ before the cells were exposed to polycations (data not shown). Spontaneous histamine release in the presence of $10 \mathrm{mM}$ or $30 \mathrm{mM}$ lidocaine were $11.6 \pm 1.9 \%(n=8)$ and $14.4 \pm 2.1 \%(n=$ 14), respectively. The inhibitory effects of 10 $\mathrm{mM}$ lidocaine on the histamine releases induced by $P E l_{6}, \mathrm{PEI}_{12}, \mathrm{PEI}_{100}, \mathrm{PAA}_{30-40}$ and PAA $A_{100}$ were partly reversed by the addition of a polycation (Fig. 3 ).

We confirmed that histamine release mediated by $\lg E$ receptors was inhibited by DSCG; the IC50 value for DSCG was $3.2 \mu \mathrm{M}$ However, DSCG $(3 \mu \mathrm{M})$ did not inhibit the histamine releases induced by $\mathrm{PEI}_{6}, \mathrm{PEI}_{12}$, $\mathrm{PEI}_{18}, \mathrm{PEl_{100 }}, \mathrm{PAA}_{30-40}$ and $\mathrm{PAA}_{100}$; the \% inhibitions were $9.5 \pm 5.5,9.8 \pm 5.5,27.9 \pm$ 


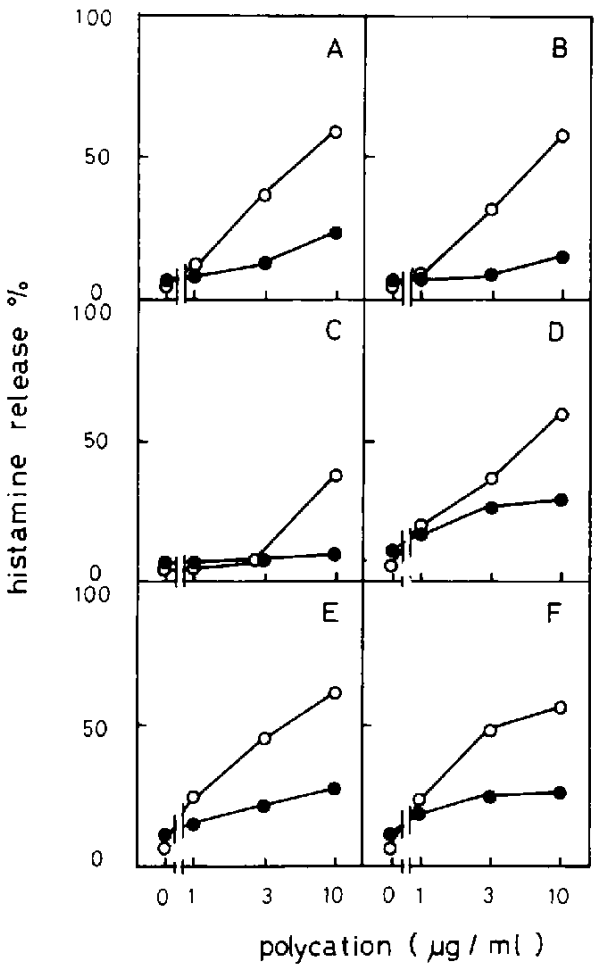

Fig. 3. Effects of lidocaine on histamine release induced by various amounts of PEls and PAAs. Purified mast cells were preincubated with $10 \mathrm{mM}$ lidocaine for $10 \mathrm{~min}$, and then the polycation (1-10 $/ \mathrm{g} / \mathrm{mil})$ was added. After $10 \mathrm{~min}$, the reactioir was stopped and the cell suspension was centrifuged. The histamine content of the supernatant was determined. Values are means \pm S.E. for 6 to 8 replicated experiments. When no vertical bar is shown. the S.E. was

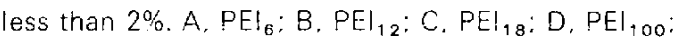
E. $\mathrm{PAA}_{30-40}: \mathrm{F}, \mathrm{PAA}_{100}$. Closed and open circles ind icate values in the presence and absence of $10 \mathrm{mM}$ lidocaine, respectively.

11.2. $6.2 \pm 10.3,12.2 \pm 12.6$ and $24.0 \pm 11.7 \%$, respectively $(n=6)$. Lidocaine inhibited the histamine release induced by compound $48 /$ 80 with an IC50 of $15 \mathrm{mM}$, but DSCG did not (data not shown).

Effects of IAP on histamine releases induced by polycations: After preincubation of mast cells with IAP, the histamine releases induced by $\mathrm{PEI}_{6}, \mathrm{PEI}_{12}, \mathrm{PE|_{100 }}, \mathrm{PAA}_{30-40}$ and $P_{A A} 100$ were significantly decreased (Fig. 4). IAP inhibited the histamine release induced by $P E I_{6}$ and $P E I_{12}$, as well as that by compound $48 / 80$, although it had less of an

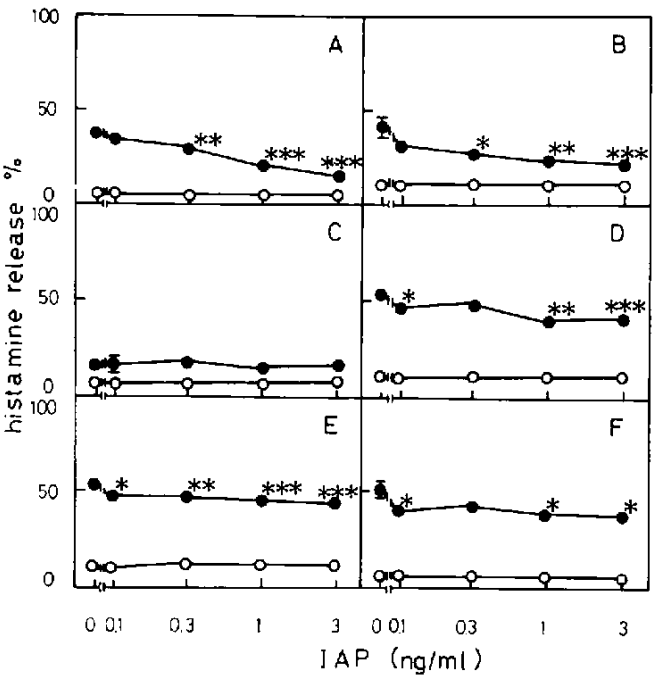

Fig. 4. Effects of IAP on histamine release induced by PEls and PAAs. Purified mast cells were preincubated with $\mid A P$ under $95 \% \mathrm{O}_{2} / 5 \% \mathrm{CO}_{2}$ at $37^{\circ} \mathrm{C}$ for $2 \mathrm{hr}$. The cells were washed twice or three times and resuspended in fresh Hepes-buffered Tyrode solution ( $\mathrm{pH} 7.4$ ) arid exposed to polycation (10 $\mu \mathrm{g} /$ $\mathrm{ml})$. After $10 \mathrm{~min}$, the reaction was stopped and the cell suspension was centrifuged. The histamime content of the supernatant was determined. Values are means $\pm S$.E. When no vertical bar is shown, the S.E. was less than $2 \%$. A, $P E I_{6}(n=6): B, P E !_{12}(n=$ 7): C. $\mathrm{PEI}_{18}(n=5):$ D. $\mathrm{PEI}_{100}(n=7):$ E. PAA $30-40$ $(n=7) ; F, P_{100}(n=6)$. Closed circles indicate histamine release induced by PEIs and PAAs, and open circles indicate spontaneous histamine release. ${ }^{*} P<0.05,{ }^{*} P<0.01$, **P $P<0.001$.

effect on the histamine releases induced by $P E I_{100}, P A_{30-40}$ and $P A A_{100}$. We confirmed the effect of IAP on the release by compound 48/80; the histamine releases induced by 1 $1 \mathrm{~g} / \mathrm{ml}$ compound $48 / 80$ in $10 \mathrm{~min}$ from mast cells preincubated with $0,0.1,0.3,1$ and 3 $\mathrm{ng} / \mathrm{ml}$ of IAP were $48.2 \pm 3.8,45.9 \pm 4.8,36.6 \pm$ $2.5(P<0.05), 20.4 \pm 2.3(P<0.01)$ and $18.4 \pm$ $1.8(P<0.01) \%$ of the total cell content, respectively $(n=6)$. Histamine release induced by $P E I_{18}$ was not affected by IAP. It is noteworthy that histamine-releasing activities of polycations, especially $\mathrm{PEI}_{18}$, were reduced after incubation of the cells in the absence of IAP for $2 \mathrm{hr}$.

Effects of GppNHp and neomycin on histamine releases induced by polycations: When the cells were permeabilized with ATP in the 


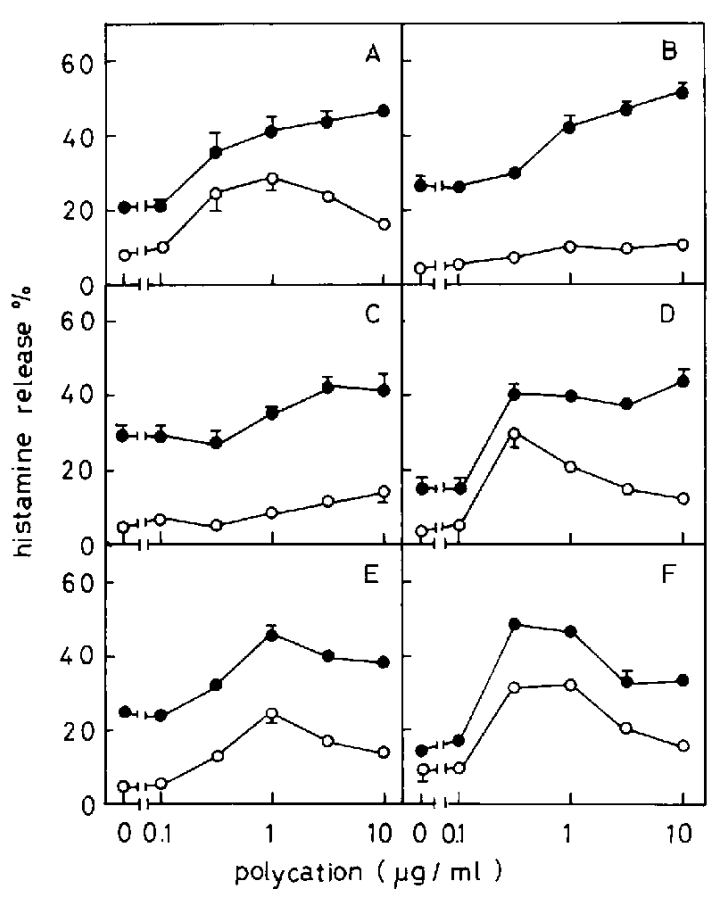

Fig. 5. Effects of GppNHp on histamine release induced by PEls and PAAs. GppNHp (1 mM) was loaded into permeabilized mast cells in the presence of $150 " \because \mathrm{M}$ ATP or in the absence of divalent cations at $37^{\circ} \mathrm{C}$ for 5 min. The cetls were resealed by adding $1 \mathrm{mM} \mathrm{MgCl}_{2}$ at $37^{\circ} \mathrm{C}$ for $5 \mathrm{~min}$ and washed in $\mathrm{Ca}$ free Hepes-buffered Tyrode solution. The washed cells were resuspended and preincubated for $5 \mathrm{~min}$. They were incubated with $1 \mathrm{~m} \mathrm{M} \mathrm{CaCl}_{2}$ for 5 min and then with polycation for $10 \mathrm{~min}$ at $37^{\circ} \mathrm{C}$. Values are means $\pm S$. . for 6 replicated experiments. When $n 0$ vertical bar is shown. the S.E. was less than $2 \%$. A.

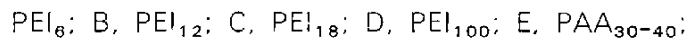
$F$. PAA 100 . Closed circles indicate histamine release from mast cells pretreated with $1 \mathrm{mM}$ GppNHp, and open circles indicate control histamine release in the absence of GppNHp

absence of divalent cations and resealed with $\mathrm{MgCl}_{2}$, the amounts of histamine released by the polycations decreased (Fig. 5, open circles). With permeabilized mast cells, histamine releases induced by $10 \mu \mathrm{g} / \mathrm{ml} \mathrm{PEI}_{6}$, $P E I_{100}$. PAA $30-40$ and $P A A_{100}$ were less than those by $1 \mu \mathrm{g} / \mathrm{ml}$ of the respective polycations (Fig. 5, open circles), while with intact mast cells, $1 \mu \mathrm{gg} / \mathrm{ml}$ polycations induced no appreciable histamine release (Fig. 3, open circles). GppNHp at $1 \mathrm{mM}$ significantly in- creased histamine release in the absence of the polycations and enhanced histamine release in the presence of polycations (Fig. 5). The enhancement of histamine release by GppNHp in the presence of $\mathrm{PEI}_{6}$ and $\mathrm{PEI}_{100}$ increased with an increase in the concentration of the polycations, while those by PAAs did not. PAAs produced a pattern of bellshaped release of histamine in the presence and absence of GppNHp.

The releases of histamine by PEIs and PAAs from resealed mast cells pretreated with neomycin are shown in Table 1. Neomycin did not inhibit or enhance the histamine releases induced by PEIs and PAAs; the differences in the release with and without neomycin cannot be regarded as significant.

Effects of lectins on histamine release induced by $\mathrm{PEI}_{6}, \mathrm{PAA}_{100}$ and compound 48/80: $P E I_{6}$ was studied further because it resembled compound $48 / 80$ as shown in Fig. 4. Effects of Con A, PHA and WGA on the histamine releases induced by $\mathrm{PEI}_{6}$. $\mathrm{PAA}_{100}$ and compound $48 / 80$ are shown in Table 2. The release induced by $3 \mu \mathrm{g} / \mathrm{ml} \mathrm{PEI}{ }_{6}$ was inhibited by WGA and PHA, but not by Con $A$. LFA, a specific lectin for sialic acid, also decreased the release of histamine induced by $\mathrm{PEI}_{6}(3 \mu \mathrm{g} / \mathrm{ml})$ from $41.1 \pm 2.0 \%(n=6)$ (in the absence of LFA) to $13.5 \pm 3.0 \%(n=6)$ (in the presence of $100 \mu \mathrm{g} / \mathrm{ml}$ LFA) of the total cell content. Moreover, the release of histamine induced by compound $48 / 80$ was inhibited by WGA and PHA, but not by Con A; $\%$ inhibition of $100 \mu \mathrm{g} / \mathrm{ml} \mathrm{WGA}$ on histamine release induced by $0.3 \mu \mathrm{g} / \mathrm{ml}$ and $1 \mu \mathrm{g} / \mathrm{ml}$ compound $48 / 80$ were $52.0 \pm 6.0 \% \quad(n=12)$ and $30.4 \pm 2.2 \% \quad(n=6)$, respectively. It is noteworthy that Con A, PHA and WGA inhibited the histamine release induced by $\mathrm{PAA}_{100}$. Under our conditions, Con A, PHA and WGA did not release histamine solely: The histamine release percents in the presence of $100 \mu \mathrm{g} / \mathrm{ml}$ Con A. PHA and WGA were $4.25 \pm 0.28 \%, \quad 5.07 \pm 0.50 \%$ and $3.62 \pm 0.50 \%$ $(n=6)$, respectively.

\section{Discussion}

We found that lidocaine inhibited histamine release induced by PEIs and PAAs. An inhibitory effect of lidocaine on the release was observed only after $10 \mathrm{sec}$ incubation with mast 
Table 1. Effects of neomycin on histamine release induced by polycations

\begin{tabular}{lcccc}
\hline & & \multicolumn{3}{c}{ Histamine release \% from mast cells pretreated } \\
Polycation & $(\mu \mathrm{g} / \mathrm{ml})$ & without neomycin & with reomycin & $\mathrm{P}$ \\
\hline $\mathrm{PEI}_{6}$ & 0 & $8.0 \pm 0.8$ &.- .3 & $>0.1$ \\
& 1 & $15.7 \pm 1.0$ & $8.3 \pm 1.3$ & $>0.1$ \\
$\mathrm{PEI}_{12}$ & 1 & $16.6 \pm 1.4$ & $20.0 \pm 2.3$ & $>0.1$ \\
$\mathrm{PEI}_{18}$ & 1 & $15.5 \pm 2.7$ & $15.9 \pm 1.7$ & $>0.1$ \\
$\mathrm{PEI}_{100}$ & 1 & $18.4 \pm 1.2$ & $23.0 \pm 3.7$ & $>0.05$ \\
$\mathrm{PAA}_{30-40}$ & 1 & $23.3 \pm 4.3$ & $22.0 \pm 1.0$ & $>0.1$ \\
$\mathrm{PAA}_{100}$ & 1 & $25.4 \pm 3.0$ & $25.3 \pm 1.7$ & $>0.1$ \\
\hline
\end{tabular}

Neomycin $(100 \mu \mathrm{M})$ was loaded into permeabilized mast cells at $37^{\circ} \mathrm{C}$ for $5 \mathrm{~min}$ in Hepes-buffered Tyrode solution ( $\mathrm{pH}$ 7.4) with $150 \mu \mathrm{M}$ ATP in the absence of divalent cations. The ceils were then resealed by

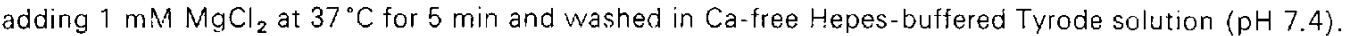
They were then incubated successively with $1 \mathrm{mM} \mathrm{CaCl}_{2}$ for $5 \mathrm{~min}$ and with polycation for $10 \mathrm{~min}$ at $37^{\circ} \mathrm{C}$. Values are given as means \pm S.E. $(n=4)$.

Table 2. Percent inhibition of histamine release induced by $\mathrm{PEI}_{6}$. $\mathrm{PAA}_{100}$ and compound $48 / 80$ from mast cells pretreated with lectins

\begin{tabular}{|c|c|c|c|c|c|c|}
\hline Releaser & $\mu \mathrm{g} / \mathrm{ml}$ & 1 & $\begin{array}{l}\text { Con A } \\
10\end{array}$ & $\mu \mathrm{g} / \mathrm{ml}$ & 100 & (n) \\
\hline$\left.P E\right|_{a}$ & 3 & $7.4 \pm 1.6$ & $2.0 \pm 4.8$ & & $9.6 \pm 3.6$ & (6) \\
\hline$P A_{100}$ & 3 & $10.3 \pm 2.7^{* *}$ & $27.0 \pm 3.0^{* * *}$ & & $37.6 \pm 2.3^{* * *}$ & (6) \\
\hline \multirow[t]{3}{*}{ Compound $48 / 80$} & 1 & $-4.1 \pm 2.3$ & $-0.3 \pm 5.1$ & & $9.1 \pm 4.4$ & (6) \\
\hline & 0.3 & $-10.0 \pm 4.7$ & $-11.1 \pm 3.4$ & & $6.2 \pm 3.3$ & (12) \\
\hline & & 1 & $\begin{array}{l}P H A \\
10\end{array}$ & $\mu \mathrm{g} / \mathrm{ml}$ & 100 & \\
\hline $\mathrm{PEI}_{6}$ & 3 & $8.2 \pm 4.0$ & $18.5 \pm 5.8$ & & $50.9 \pm 4.5^{* * *}$ & (6) \\
\hline $\mathrm{PAA}_{100}$ & 3 & $14.9 \pm 2.8^{* * *}$ & $17.7 \pm 2.0^{* * *}$ & & $29.7 \pm 1.9^{* * *}$ & (6) \\
\hline \multirow[t]{4}{*}{ Compound $48 / 80$} & 1 & $-2.8 \pm 2.9$ & $8.8 \pm 2.4^{*}$ & & $1.1 \pm 5.0$ & (6) \\
\hline & 0.3 & $14.2 \pm 5.3^{*}$ & $18.4 \pm 2.2^{* * *}$ & & $25.0 \pm 4.1^{* * *}$ & (6) \\
\hline & & & WGA & $\mu \mathrm{g} / \mathrm{ml}$ & & \\
\hline & & 1 & 10 & & 100 & \\
\hline $\mathrm{PEI}_{6}$ & 3 & $8.2 \pm 3.8$ & $27.1 \pm 2.3^{* * *}$ & & $72.7 \pm 3.0^{* * *}$ & (6) \\
\hline PAA $_{100}$ & 3 & $14.9 \pm 7.0$ & $26.1 \pm 2.8^{* * *}$ & & $47.5 \pm 3.0^{* * *}$ & (6) \\
\hline \multirow[t]{2}{*}{ Compound $48 / 80$} & 1 & $-3.7 \pm 2.1$ & $2.0 \pm 4.6$ & & $30.4 \pm 2.2^{* * *}$ & (6) \\
\hline & 0.3 & $3.7 \pm 3.2$ & $28.8 \pm 6.1^{* * *}$ & & $52.0 \pm 6.0^{* * *}$ & (12) \\
\hline
\end{tabular}

After preincubation with various lectins for $10 \mathrm{~min}$ in Hepes-buffered Tyrode solution $(\mathrm{pH} 7.4$ ), the mast cells were incubated with $\mathrm{PEI}_{6}$, PAA 100 and compound $48 / 80$ for $10 \mathrm{~min}$ at $37^{\circ} \mathrm{C}$. Percent inhibition was calculated as described in Materials and Methods. Values are given as means $\pm S .5 .{ }^{*} P<0.05$. ${ }^{* *} P<0.01,{ }^{* * *} P<0.001$.

cells, like the case of the release induced by compound $48 / 80(10)$. Its effects on mast cells did not change the histamine release induced by polycations with various degrees of polymerization (Fig. 2). Its inhibitory effects were partly reversed by a polycation (Fig. 3). Thus, the effects of lidocaine on the histamine release induced by polycations are similar to that on the release induced by compound $48 /$ 80. One of the mechanisms for the inhibitory effect of lidocaine on histamine release induced by Con A was due to inhibition of calcium influx into mast cells (14). However, lidocaine inhibits the histamine release induced by calcium ionophore A23187 when there is enough intracellular calcium to trigger 
histamine releases, suggesting that their inhibitory actions on histamine release induced by $A .23187$ cannot be explained by their effect on calcium influx (14). Our group previously reported that the inhibitory effects of lidocaine on mast cells was correlated with the concentration of nonionized molecules which penetrate the mast cell membrane (10). The site of action for lidocaine on mast cells is still unknown, but lidocaine may interfere with steps in the release cascade that occurred after opening of calcium channels, such as calmodulin-dependent ones (15).

DSCG inhibits calcium influx into the mast cells to inhibit histamine release induced by antigens (5), because it binds to cromolynbinding protein, which is thought to be a component of the innate calcium channels of mast cells $(16,17)$. DSCG. however, did not inhibit histamine release induced by PEls or PAAs. Thus an inhibitor of both histamine releases induced by antigens and compound $48 / 80$ inhibited the release induced by PEIs and PAAs, although a specific inhibitor of histamine release induced by antigens did not.

Histamine is released from permeabilized mast cells on activation of their $G$ protein by GTP-r-S [guanosine-5'-O-(3-thiotriphosphate)] or $\operatorname{GppNHp}(11,12)$. This activation is inhibited by pretreatment of the mast cells with IAP. which also inhibits histamine release from basophils $(6,18,19)$, although cholera toxin potentiates serotonin release from basophi! leukemia cells, but does not affect histamine release from mast cells $(20,21)$. We found that IAP inhibited histamine release induced by all the polycations we tested. except $\left.P E\right|_{18}$, suggesting that the histamine releases induced by some polycations seemed to be mediated by $G$ protein, like the release by compound $48 / 80$ (Fig. 4). This was confirmed in the experiments using GppNHp (Fig. 5). In the absence of GppNHp, $P E I_{6}, P E I_{100}$. $\mathrm{PAA}_{30-40}$ and $\mathrm{PAA}_{100}$ produced the pattern of bell-shaped histamine release, like antiIgE (22). Only PAAs produced the pattern of bell-shaped histamine release in the presence and absence of GppNHp, suggesting that interactions of PAAs with mast cells were somewhat different from those of PEIs.

Gomperts and Fewtrell (23) reported that GDP- $\beta$-S [guanosine-5'-O-(2-thiodiphos- phate)] is an inhibitor of secretion when introduced through a patch pipette, but that it behaves as an activator when trapped in the cytosol by permeabilization and resealing. Our preliminary data showed that GDP- $\beta-S$ also activated the histamine releases by PEls and PAAs from permeabilized mast cells, and that when loaded into mast cells at $1 \mathrm{mM}$ concomitantly with GppNHp, it did not inhibit enhancement by GppNHp of histamine release by PEls and PAAs. It is interesting that $\mathrm{GppNHp}$ increases histamine release induced by $P E I_{18}$, although IAP did not inhibit histamine release induced by $P E I_{18}$. It remains possible that $\left.P E\right|_{18}$ activates $G$ proteins and triggers the release of histamine.

Neomycin at $100 \% \mathrm{M}$ inhibits histamine release and polyphosphoinositide phosphodiesterase of mast cells permeabilized by ATP (12), but did not inhibit them in the cells permeabilized by streptolysin-O (24). Since it did not inhibit the histamine release induced by PEIs and PAAs (Table 1), we supposed that PEls and PAAs can trigger histamine release by by-passing the activation of polyphosphoinositide phosphodiesterase. However, our attemps to determine the intracellular concentration of inositol triphosphate were unsuccessful.

Secretion from platelets is also dependent on $G$ protein (25), but PEls and PAAs did not activate serotonin release from rat platelets (2). We then supposed that mast cells have some binding sites for PEIs and PAAs. A mast cell has the binding sites for compound $48 / 80$ on its cell membrane (26). The binding site may be composed of proteins (27) with sialic acid (28). The binding sites for PEls and/or PAAs may partially overlap those for compound $48 / 80$. To confirm, we examined the effects of lectins on histamine release induced by $\mathrm{PEI}_{6}, \mathrm{PAA}_{100}$ and compound $48 / 80$. Lectins recognize specific sugar residues: Con A is specific for mannoside: PHA, for $\mathrm{N}$-acetyl galactosamine; and WGA, for $\mathrm{N}$ acetyl glucosamine and sialic acid. Con $A$ and WGA induced release of histamine potentiated by phosphatidylserine $(29,30)$. Under our conditions, however, no appreciable release of histamine was observed in the presence of the lectins tested. The concentration of lectins we used seemed to be 
enough to interfere with the interaction of polycations with mast cells; at the concentration of $100 \mu \mathrm{g} / \mathrm{m}$ ! of Con A. PHA and WGA, there are $2.32 \times 10^{8}, 2.02 \times 10^{8}$ and $5.56 \times 10^{8}$ molecules of lectin/mast cell, respectively.

Experimental data led to the hypothesis that the binding sites of $\mathrm{PEI}_{6}$ and compound 48/ 80 have sugar residues of sialic acid, $N$ acetyl glucosamine and/or $\mathrm{N}$-acetyl galactosamine; and those of $\mathrm{PAA}_{100}$ have sialic acid, $\mathrm{N}$-acetyl glucosamine, $\mathrm{N}$-acetyl galactosamine and mannose. The binding of $\mathrm{PEI}_{6}$ to mast cells seemed to be inhibited by WGA due to its affinity to sialic acid rather than to its affinity to $\mathrm{N}$-acetyl glucosamine, because LFA that is specific for sialic acid reduced histamine release induced by $\mathrm{PEI}_{6}$. PAA 100 can bind to the binding sites of compound $48 / 80$, but it can also bind to the other binding sites with mannose. Table 2 shows that $\mathrm{PEI}_{6}$ interacted with sialic acid and/or $\mathrm{N}$-acetyl galactosamine of the binding sites of compound 48/80, but not with mannose of Con $\Delta$-receptor, including $\lg \mathrm{E}$ receptors (31). Therefore, the mechanisms of histamine release induced by $\mathrm{PEI}_{6}$ resembled those by compound $48 / 80$ rather than those by antigens. The binding of compound $48 / 80$ or $\mathrm{PE}_{6}$ to their binding sites of mast cells seemed to activate $G$ protein to release histamine from the mast cells. However, it is not clear whether the binding sites for compound $48 /$ 80 and $P E I_{6}$ are coupled to $G$ protein of the mast cells directly or secondarily.

Acknowledgments: The authors thank Drs. N. Oku and $M$. Nango for kind gifts of PEls alid PAAs. This work was supported in part by a Grant-in-Aid for Scientific Research from the Ministry of Education. Science and Culture of Japan.

\section{References}

1 Oku, N., Yamaguchi, N., Yamaguchi, N., Shibamoto, S., Ito, F. and Nango, M.: The fusogenic effect of synthetic polycations on negatively charged lipid bilayers. J. Biochem. 100, 935-944 (1986)

2 Suzuki-Nishimura, T., Sekino, H., Yoshino, Y., Nagaya, K., Oku, N., Nango, M. and Uchida, M.K.: Synthetic polycations, polyethylenimines and polyallylamines release histamine from rat mast cel!s. Japan. J. Pharmacol. 51, 279-290 (1989)

3 Koibuchi, Y., Ichikawa, A., Nakagawa, M. and
Tomita, K.: Histamine release induced from mast cells by active components of compound $48 / 80$. Eur. J. Pharmacol. 115, 163-170 (1985)

4 Suzuki, T., Mori, K. and Uchida, M.: Inhibition by calcium antagonists of histamine release and calcium influx of rat mast cells: Difference between induction of histamine release by concanavalin A and compound 48/80. Eur. J. Pharmacol. 85, 155-161 (1982)

5 Pearce, F.L., Atkinson, G., Ennis, M., Truneh, A., Weston, P.M. and White, J.R.: Effect of antiallergic compounds on histamine release induced by basic agents, antigen and the calcium ionophore A23187. In The Mast Cell; Its Role in Health and Disease, Edited by Pepys, J. and Edwerds, A.M., p. 69-75. Pitman Medical. Kent (1979)

6 Nakamura, T. and Ui, M.: Suppression of passive cutaneous anaphylaxis by pertussis toxin, an islet-activation protein, as a result of inhibition of histamine release froni mast cells. Biochem. Pharmacol. 32, 3435-3441 (1983)

7 Higashijima, T., Uzu, S., Nakajima, T. and Ross, E.M.: Mastoparan, a peptide toxin from wasp venom. mimics receptors by activating GTP. binding regulatory proteins ( $\mathrm{G}$ proteins). J. Biol. Chem. 263, 6491-6494 (1988)

8 Sullivan, T.J., Parker, K.L., Eisen, S.A. and Parker, C.W.: Modulation of cyclic AMP in purified mast cells. I!. Studies on the relationship between intracellular cyclic AMP concentrations and histamine release. J. Immunol. 114, 1480-1485 (1975)

9 Kazimierczak, W., Peret, M. and Maslinski, C.: The action of local anesthetics on histamine release. Biochem. Pharmacol. 25, 1747-1750 (1976)

10 Suzuki, T., Ohishi, K. and Uchida, M.: Influence of $\mathrm{pH}$ on the inhibitory effects of local anesthetics on histamine release induced from rat mast cells by concanavalin $A$ and compound 48/80. Eur. J. Pharmacol. 98, 347-355 (1984)

11 Gomperts, B.D.: Involvement of guanine nucleotide-tinding protein in the gating of $\mathrm{Ca}^{2+}$ by receptors. Nature 306, 64-66 (1983)

12 Cockcroft, S. and Gomperts, B.D.: Role of guanine nucleotide binding protein in the activation of polyphosphoinositide phosphodiesterase. Nature 314, 534-536 (1985)

13 Shore, P., Burkhalter, A. and Chon, V.: A method for fluorometric assay of histamine in tissue. J. Pharmacol. Exp. Ther. 127, 182-186 (1959)

14 Ohishi, K., Suzuki, T. and Uchida, M.K.: Different effects of local anesthetics on calcium influx into rat mast cells stimulated by concanavalin $A$ and 
A23187. Gen. Pharmacol. 16, 199-203 (1985)

15 Suzuki, T., Ohishi, K. and Uchida, M.K.: Effects of calmodulin inhibitor on histamine release from rat peritoneal mast celis induced by concanavalin A and ionophore A23187. Gen. Pharmacol. 14. 273-275 (1983)

16 Mazurek, N., Berger, G. and Pecht, I.: A binding site on mast cells and basophils for the antiallergic drug cromolyn. Nature 286, 722-724 (1980)

17 Henmerich, S. and Pecht, I.: Isolation and purification of an $\mathrm{FC}_{\bar{z}}$ receptor activated ion channel from mast cell line RBL-2H3. Biochemistry 27, 7488-7498 (1988)

18 Nakamura, T. and Ui, M.: Islet-activating protein, pertussis toxir, inhibits $\mathrm{Ca}^{2+}$-induced and guanine nucleotide-dependent releases of histamine and arachidonic acid from rat mast cells. FEBS Lett. 173, 114-418 (1984)

19 Saito, H., Okajima, F., Molski, T.F.P., Sha'afi, R.I., Ui, $M$, and Ishizaka, T.: Effects of ADPribosylation of GTP-binding protein by pertussis toxin on immunoglobulin E-dependent and -independent histamine release from mast cells and hasophils. J. Immunol. 138, 3927-3934 (1987)

20 Saito, H., Okajima, F., Molski, T.F.P., Sha'afi, R.I., Ui, M. and Ishizaka, T.: Effect of cholera toxin on histamine release from bone marrow-derived mouse mast cells. Proc. Natl. Acad. Sci. U.S.A. 85, 2504-2508 (1988)

21 McCloskey, M.A.: Cholera toxin potentiates IgE-coupled inositol phospholipid hydrolysis and mediator secretion by RBL- $-2 \mathrm{H} 3$ cells. Proc. Natl. Acad. Sci. U.S.A. 85, 7260-7264 (1988)

22 Foreman, J.C, and Lichtenstein, L.M.: Induction of histamine secretion by polycations. Biochini. Biophys. Acta 529, 587-603 (1980)

23 Gomperts, B.D. and Fewtrell, C.M.S.: The mast cells, a paradigm for receptor and exocytotic mechanisms. In Molecular Mechanisms of Tränsmenibrane Signalling. Edited by Cohen. P. and Houslay, M.D., p. 377-409. Elsevier Sci. Pub., Amsterdam (1984)

24 Cockcroft, S., Howell, T.W. and Gomperts, B.D.: Two G-proteins act in series to courit stimulussecretion coupling in mast celis: Use of neomycin to distinguish between $\mathrm{G}$-proteins controlling polyphosphoinositide phosphodiesterase and exocytosis. J. Cell Biol. 105, 2745-2750 (1987)

25 Haslam, R.J. and Davidson, M.M.L.: Guanine nucleotides decrease the free $\left[\mathrm{Ca}^{2+}\right]$ required for secretion from permeabilized blood platelets: evidence of a role for a GTP-binding protein in platelet activation. FEBS Lett. 174, 90-100 (1984)

26 Hino, R.H., Lau, C.K.H. and Read, G.W.: The site of action of the histamine releaser compound $48 / 80$ in causing mast cell degranulation. J. Pharmacol. Exp. Ther. 200, 658-663 (1977)

27 Ortner, M.J. and Chignell, C.F.: Spectroscopic studies of rat mast cells, mouse mastocytoma cells and compound 48/80- III; evidence for a protein biriding site for compound $48 / 80$. Biochem. Pharmacol. 30, 1587-1594 (1981)

28 Adamczyk-Engelmann, $P$, and Bader, $H_{\text {.: }}$ The role of membrane bound sialic acid of rat mast cells in histamine release induced by compound $48 / 80$ and derivatives as well as calcium. Agents Actions 28, 34-38 (1989)

29 Lansman, J.B. and Cochrane, D.F.: Wheat germ agglutinin stimulates exocytotic histamine secretion from rat mast cells in the absence of extracellular calcium. Eiochem. Pharmacol. 29, 455-458 (1980)

30 Ennis, M., Truneh, A. and Pearce, F.L.: Lectininduced histamine secretion from isolated rat and guinea pig mast cells. Biochem. Pharmacol. 30, 2179-2181 (1981)

31 Foreman, J.C., Hallett, M.B. and Monger, J.L.: The relationship between histamine secretion and ${ }^{45} \mathrm{Ca}$ uptake by mast cells. J. Physiol. (Lond.) $271,193-214$ (1977) 